died in 1912 at the age of 40 - Shelford worked in Oxford, painstakingly sorting out his notes and exquisite drawings and photographs. He died before the work was ready for publication. Edward Poulton, then professor of zoology at Oxford, edited the work and this is the volume which has now been re-issued. It is a tidy and systematic description of the mammals, birds, snakes, cockroaches (a special interest he had), beetles and ants in Sarawak; a thoroughly professional job, but told in an engaging way which will appeal to the same wide audience that finds David Attenborough's films so compelling.

If I had to recommend only one of these books, it would be the third, by Charles Hose. Despite its silly title, which leads one to expect pompous recollections from some bewhiskered ex-Indian civil servant from Cheltenham, it is learned, charming and scientifically credible. Of the three, it is the only one that gives the impression that here is a man permeated by the environment of Sarawak. This is not surprising, for Charles Hose was a senior official in Rajah Brooke's government and a member of the Supreme Council. He served there from 1884 to 1907 , although his notebooks were not published until 1929. His style is conversational, as if conducting a leisurely tour: sailing along the Bornean coast he draws the reader's attention to fish, to turtles, to birds, with acute observations about each of them, clearly the fruit of years of experience. His comments about the people, too, are of a much higher quality than those of Bock or even Shelford; Hose spoke their languages, knew them as individuals and wrote about them with affection, as fellow citizens, not as subjects of the "white man's burden".

This book, I believe, reproduces something for which there are few modern equivalents, namely the deep-rooted intimacy of an outsider with an exotic foreign country. Even the most lavishly equipped film-team cannot acquire that intimacy; and these days fewer and fewer Westerners have opportunities to spend decades in such alien societies. The surprising feature of The Field-Book of $a$ Jungle-Wallah is that it is as authoritative and precise in its observations of nature as Shelford's book, although natural history for Hose was a hobby, to be enjoyed in the time he could spare from administration and the duties of high office.

All of these books are, in their different ways, most enjoyable reading. They will also remind the maker of nature-films that he owes a debt to his forerunners who put laboriously into print what they, more swiftly, now put on to celluloid.

Lord Ashby, formerly Professor of Botany at the University of Sydney and the University of Manchester, is a Fellow of Clare College, Cambridge CB2 ITL, UK.

\section{Colour impressions of history}

\section{J.D. Mollon}

Jacob Christoph Le Blon 1667-1741: Inventor of Three- and Four-Colour Printing. By Otto M. Lilien. Anton Hiersemann, Postfach 723, Rosenbergstrasse 113, D-7000 Stuttgart 1, FRG: 1985. DM 180.

DEspite the seemingly endless variety of our visual sensations, our colour vision depends on the presence in the retina of just three classes of cone, each containing a different photo-sensitive pigment. It is for this reason that colour reproduction is relatively easy: in each local area of the image, we must merely arrange that three printing inks or three television phosphors stimulate the viewer's cones in the same ratios as would the original object

The principle of three-colour reproduction was exploited in practice before its theoretical basis was understood. The three-receptor theory of vision did not emerge until the end of the eighteenth century, but colour printing had already been brought almost to perfection by its quixotic inventor, Jacob Christoph Le Blon, a miniaturist and mezzotint engraver who was born in Frankfurt in 1667. Horace Walpole said of Le Blon:

He was... of surprising vivacity and volubility, and with a head admirably mechanic, but an universal projector, and with at least one of the qualities that attend that vocation, either a dupe or a cheat;... perhaps like most enthusiasts he was both one and t'other.

Le Blon has long been a shadowy and enigmatic figure and we may warmly welcome O.M. Lilien's careful biography.

Lilien has eschewed the often fanciful accounts of Le Blon in the secondary literature, and, combining scholarship with enterprise, has scoured Europe for contemporary material, in civil archives and in printed sources. He is thus able to provide us with a firm, though somewhat spare, reconstruction of Le Blon's career. Many of the more important documents are reproduced. Lilien discusses in detail the editions of Le Blon's book Il Coloritto, in which the principle of trichromatic colour-mixing is set out. He reprints in full the text of the first edition. However, although Lilien is a historian of printing, there are some gaps in his account of Le Blon's printing technique. It took Le Blon a long time to find inks with the necessary properties, but Lilien does not discuss their composition, although they are identified in eighteenth-century sources (for example Dossie's Handmaiden to the Arts of 1764) and although they could be identified spectrophotometrically from surviving prints.
One of the most important documents considered by Lilien is a holograph prospectus for the "Picture Office", the illfated printing company that Le Blon established in London. In translating from this French manuscript to English, Lilien corrupts one very interesting passage (cf. pp.28, 30 and 115 of his book). We can readily forgive him, since neither French nor English is his native language. But the passage throws an intriguing light on Le Blon's understanding of trichromacy. My own translation would be as follows:

In searching for general rules that would allow one to reduce to solid, reliable and easy practice that part of painting called Coloris by painters, I perceived that my project would be prac-

\section{Of Preliminaries.}

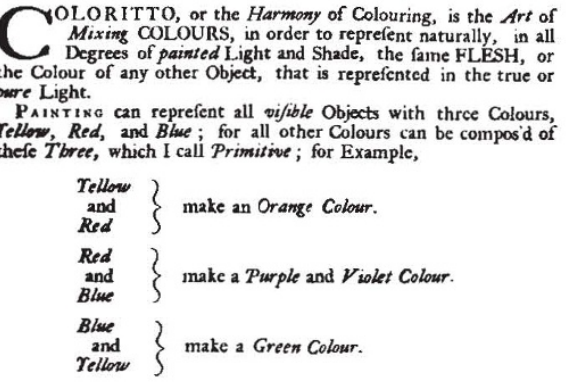

And a Mixture of thofe Three Original Colours makes a Black, and all ot ber Colours whatinever; as I have demonftrated by my in vention of Printing Pictures and Pigures with their natural Colower. I am only fpeaking of Material Colours, or thofe ufed by Pain. ters; for a Mixture of all the prunitive impalpable Colours, that so the Great Sir I not produce Black, but the very Contrary, Whire;

White, is a Concentering, or an Excefs of Lights. Black, is a deep Hiding, or Privation of Lights.

Mixed interpretation - the opening page of Le Blon's Il Coloritto. The book was first published in 1725 .

ticable if I could find among material colours the perfect primitive colours. Having then at last found material colours that came so close to the primitive colours that there was no tint that could escape me and not be reproduced by my colours, I began to realize that, according to these principles, painting could perfectly represent all visible objects not only by the brush but also by the printing press

There is a strong hint here that by $1721 \mathrm{Le}$ Blon had already distinguished in his mind between the most saturated material colours and hypothetical primitives or primaries. This important distinction was to become critical in the later understanding of colour vision and it took Clerk Maxwell and Helmholtz to grasp that each of the hypothetical primaries would represent unique excitation of one receptor type something that a physical stimulus can only approach.

There is still much work to be done on Le Blon, on his techniques and on his theoretical understanding. But Lilien has provided us with an authoritative and richly illustrated biography that will not quickly be surpassed.

J.D. Mollon is a Lecturer in the Department of Experimental Psychology, University of Cambridge, Downing Street, Cambridge CB2 $3 E B, U K$. 